Olena Baula,

Candidate of Economic Sciences, Associate Professor, Associate Professor of the Department of International Economic Relations, Lutsk National Technical University (Lutsk, Ukraine);

Natalia Galaziuk,

Candidate of Economic Sciences, Associate Professor, Associate Professor of the Department of International Economic Relations, Lutsk National Technical University (Lutsk, Ukraine);

Olga Zelinska,

Candidate of Economic Sciences, Associate Professor, Associate Professor of the Department of International Economic Relations, Lutsk National Technical University (Lutsk, Ukraine)

\title{
CONCEPTUAL FRAMEWORK FOR ORGANIZATIONAL AND ECONOMIC MECHANISM FORMATION TO INCREASE THE REGION COMPETITIVENESS WITH THE GLOBALIZATION OF THE WORLD ECONOMIC RELATIONS
}

To allocate macroeconomic and institutional factors of formation of competitive advantages of the region, develop the conceptual bases of formation of organizational and economic mechanism of increase of region competitiveness in the conditions of globalization of the world economy. Macroeconomic and institutional effective factors of region competitiveness were allocated on the basis of theoretical analysis of competitive advantages of the region, generalization and systematization of the views of economists. Organizational and economic mechanism of increase of region competitiveness in the conditions of globalization of the world economy was suggested. The conceptual bases of formation of organizational and economic mechanism of increase of region competitiveness in the conditions of globalization of the world economy were improved. These principles take account of macroeconomic and institutional competitive advantages that will guarantee the integrity of the state through the sustainable development of all regions of the country. The formation of conceptual bases of formation of organizational and economic mechanism of increase of region competitiveness is the basic condition for determining of the instruments of regional economic policy of the government. Raising the level of efficiency of technological and resource potential of the region as a result, improving the welfare of the population.

Keywords: competitive advantages, region competitiveness, sustainable development of the region, mechanism of management of region competitiveness, globalization of world economic relations

DOI: 10.21272/mmi.2017.2-07

Introduction. The modern stage of world development is characterized by the proliferation of globalization and regionalization, which, on the one hand contributes to the development of the competitive processes at all levels of the economic system, and on the other hand transfers centres of the competition at the regional level and the growing role of the regions in the formation of the competitive advantages of the country. The region is gradually becoming a relatively independent economic entity which enters into competitive relations in the inter-regional interactions as well as international. The phenomenon of asymmetry in the competitive environment and its transformation under the influence of the global world's development causes the necessity of the formation of effective factors of competitive advantages of a particular region for the formation of the mechanism of management of its competitiveness that will determine the satisfaction of not only regional interests but of the interests of the whole state.

Brief literature review. The theory of competitive advantages were considered in the days of A. Smit [11], modern directions of researches have been developed by such foreign scientists as 
B. Asheim [15], I. Begg [16], M. Porter [8; 9], B. Lundvall [20], C. Jensen-Butler [19], B. Gardiner [18], M. Enright [17] and others. Russian and Ukrainian researchers, especially B. Anderson [1], L. Antoniuk [2], B. Bezugla [3], P. Bielienkyi [12], E. Briuna [4], Z. Herasymchuk and L. Kovalska [5], N. Kaliuzhnova [6], A. Selieznov [10] and many others have also devoted their works to the problem of maintenance of competitive advantages of the country and the region.

Despite the significant contribution of the scientists mentioned above, the existent theoretical and applied researches of the formation of competitive advantages of regions need to be improved, as well as the conceptual bases of formation of organizational - economic mechanism of increase of competitive advantages of the region, which would include accounting, macroeconomic and institutional formation of effective factors that will ensure the sustainable development of the regions of the country.

In foreign and national scientific practice the competitive advantages of regions and their contributing factors are widely considered. The researchers prove that investments, innovations and a highly skilled workforce are the foundation on which the competitive advantages of the regions of the country are based. They consider that just new forms of organization of social production will ensure sustainable development of the region.

At the same time, in the works of national researchers not enough attention is paid to the institutional components of competitive advantages of the region, which in the combination with the macroeconomic competitive advantages will ensure the formation of the effective organizational and economic mechanism of increase of region competitiveness, it will determine the implementation of both economic and public interests, create a friendly environment to the potential implementation of all participants in the economic process.

Different focus of scientists' researches as to the identifying of the base and derived the formation of effective factors of competitive advantages of the region determine the necessity for further researches in this direction, and also requires justification of organizational and economic mechanism of management of region competitiveness in the conditions of globalization of world economic relations.

The aim of the article is to explore the competitive advantages that form and develop the competitiveness of the region, to substantiate the necessity of consideration of the macroeconomic and institutional factors in the formation of the organizational and economic mechanism of increasing of region competitiveness in the conditions of globalization of the world economy.

Results. At present Ukraine is in the international competitive environment to which the national economy was unprepared mainly through the unequal development of the regions of the country, which in turn determines the competitiveness of domestic products, the irrational structure of industry, inefficient use of production factors, low home demand, and insufficient motivation to increase production efficiency.

Many questions remain undecided despite the significant scientific interest to the questions of region competitiveness. First of all it concerns the determination of the competitive advantages that form and develop the region competitiveness from the position of influence of macroeconomic and institutional factors.

The representative of classical political economy A. Smith proved that prosperity of the country, region depends on the level of the industry development due to division of labour and cooperation based on the principle of absolute advantage [11, p. 13-14].

The Professor of the Institute For Strategy And Competitiveness at Harvard Business School M. Porter has proved that wealth of the country is created, not inherited. It does not arise from the natural resources of the country, its labour potential as representatives of the classical economic theory claim but it depends on the ability of its industry to innovations and modernization. Competitive advantages create the wealth of a country (region). To assess regions competitiveness M. Porter has developed a model of "national competitive advantages", which is based on the interaction of the main 
О.В. Баула, Н.М. Галазюк, О.М. Зелінська. Концептуальні засади формування організаційно-економічного механізму підвищення конкурентоспроможності регіону в умовах глобалізації світогосподарських зв'язків

(the terms of the demand, the condition of inputs, allied and supporting industries, firms' strategies) and additional determinants (government, occurrence) [8, p. 21]. The value of the M. Porter's concept is that it allows determining the stages of the development of the country (region) and mechanisms to improve its competitiveness, i.e. it can be used to develop national and regional strategies for economic development. According to Porter's thought the region can achieve high productivity only if there are close ties between industrial brunches of the respective companies [8, p. 257-260]. Porter assigns an important role to the regional factors of competitiveness: "It is paradoxical but long-term competitive advantages in the global economy are in the local stuff - knowledge, relationships, motivation, that like distant rivals can't compete" [9, p. 275].

Porter's views has received further development in the research of $\mathrm{M}$. Enright who substantiated the need for a regional cluster based on competitive advantages due to the historical background of the development of the regions, business culture, management and education [17, p. 21].

Danish economists B. Lundvall and B. Johnson researched competitive innovative development of small countries, which is offered to provide through the active introduction of additional innovations and training (a continuous improvement process skills for the production of a new product of labour) taking into consideration the consumers' needs [20, p. 24-40]. Scientists have built the institutional scheme of the national system of innovation that combines the interaction of participants in the learning process and the search for new knowledge that is determined by the R\&D sector.

Norwegian scientists, the authors of the theory of regional competitiveness B. Asheim and A. Isaksen consider industrial areas in the regions as a source of innovation where knowledge transfer is more efficient in direct communication. According to them the basis of the competitive advantages of the region is their innovative development, which is possible by combining local (regional) and global (exogenous) knowledge [15, p. 79-86].

In this context the theory of competitiveness of cities deserves special attention. Italian scientist I. Begg supposes that the main competitive advantage of cities is the productivity and employment, the efficiency of which is expressed by the achievement of the local population. Moreover, I. Begg thinks that the main factors of regional competitiveness are changes in the ratio of types of economic activity and macro view on the region. I. Begg considers the main factor of effective competitive advantages of the region is the efficient use of inputs; living standard of the local population is a characteristic which indicates the result of regional competitiveness [16, p. 796-802]. English scientist C. Jensen- Butler refers the following things to the main factors of competitiveness of cities (regions): industry structure, innovations, the concentration of skilled labour, the class structure, the successful management of conflicts, availability and the level of public goods, reducing the influence of negative externalities, high incomes, high levels of employment [19, p. 6-40].

The Cambridge University researchers R. Martin, B. Gardiner, P. Tyler emphasize the importance of institutional and market structures of the region as factors of increasing its competitiveness and focus on productivity as a key indicator of the competitiveness of the region [18, p. 1048]. In their model the main component of efficiency of economic development of the region is the increase in the quality of life of the population.

In this aspect the views of the Russian scientists-economists are interesting and useful. A. Selieznov believes that the competitiveness of the region is conditioned by the economic, social, political and other factors in the position of the region and its individual producers on home and foreign markets, which is reflected through the indicators that characterize adequately such condition and its dynamics [10, p. 30]. E. Bruina and A. Skopin consider the region's competitiveness as the ability of the regional economy to ensure the welfare of the population of the region in an open economy. In their opinion the effective regional economy can ensure the welfare of the population of the region using only qualitative factors of production, creating an entirely new sector of the information economy and diversifying it [4]. 
According to N. Kaliuzhnova available and creating/emerging competitive resources are the sources of competitive advantages.

The scholar determines such criteria of competitiveness of the region as economic growth, the production of competitive goods and the rising standard of living of the population. And the management of the competitiveness of the region is the maintenance and consolidation of the positions among the regions of competitors by creating new structural combinations of the use of the resources [6, p. 10-16].

National scientists also pay much attention to identifying the factors of competitive advantages of regions of the country, despite the rapid growth of competition between them and the irreversible processes of globalization. In particular, Anderson believes that the competitiveness of the region is determined, on the one hand, by the fact that the region has competitive industries and segments of the economy, and on the other hand by the ability of regional authorities to create conditions for enterprises in the region to enable them to achieve and maintain a competitive advantage in certain industries. Highly competitive regions should function as "a gateway into the global world" [1]. L. Antoniuk has directly connected the competitiveness of the region with innovative economy based on the knowledge [2, p.152]. V. Bezuhla connects the competitiveness of the region with the ability of each regional system to manage its competitive advantages, rational and effective allocation of productive forces with the goal of providing sustainable financial and economic situation, to gain maximum benefit, the satisfaction of objective and subjective needs in terms of autonomy and self-financing in the framework of current legislation [3, p. 12-16].

P. Bielienkyi identifies the competitiveness of the region with its ability to provide a high standard of living and the incomes of the capital owners', and to use effectively the regional economic potential in the process of production of goods and services [12, p. 13].

Z. Herasymchuk and L. Kovalska consider the competitiveness of the region as the ability to provide a competitive advantage in the productive use of resources and benefits with the aim of improving human development without disrupting the economic security of the other regions and the country as a whole [5, p.39]. O. Liutak believes that the competitiveness of the region should be based on the full use of all possibilities of cross-border cooperation that would strengthen the overall competitive advantages of the region in macroeconomic and global scale [7, p. 278-279].

Despite the assessment of the theoretical treatments of the researchers of competitiveness we consider to make the following conclusions: scientists, foreign and national, are united in the opinion that the region's competitive advantages arise and increase by investment, technological innovations and highly qualified employees; scientists prove that at the regional level it is reasonable to develop new forms of production organization - industrial districts, which will act as indicators of competitiveness of regions, which, in turn, is a synthesis of the advantages and disadvantages of the four components of the systems - social, economic, technological-innovation and environmental sector.

In our opinion, the world practice proves that due to the means of a rational economical regional policy it is possible to provide the high dynamism of development of regions, to form a strong tendency to turn them into important centres of growth that will compete in the world market at the level of states. Such a fundamental change of orientation can approve a new system of values and formation of new trends in the European economic area. However, to achieve such results for economic development and income growth it is insufficient to supply economic and technical conditions, it is also important to guarantee macroeconomic and institutional environment - the set of fundamental political, legal and social rules and norms, where economic and technical advantages will be used.

The establishment of the effective macroeconomic and institutional environment will contribute to the completion of the market economy transformation and effective integration into the world economic space, the reduction of transaction costs of economic entities in the region and, as a result, improving the efficiency of resource use. 
О.В. Баула, Н.М. Галазюк, О.М. Зелінська. Концептуальні засади формування організаційно-економічного механізму підвищення конкурентоспроможності регіону в умовах глобалізації світогосподарських зв'язків

Despite such emphasis of our research, we believe that to provide the high dynamism of development of regions, to form a stable tendency of turning them into important centres of growth that will compete in the world market at the level of states is possible by means of rational economicregional policy. In our opinion, the optimal set of instruments of regional economic policy is possible to form only after the determination of competitive advantages that form and develop region competitiveness from a position of influence not only macroeconomic but also the institutional factors. The next step of our study will be the allocation of macroeconomic and institutional factors of formation of competitive advantages of the region, due to which we denote the conceptual foundations of organizational-economic mechanism of increase of region competitiveness in the conditions of globalization of the world economy development.

Under the institutional environment of the region we understand the totality of fundamental political, legal and social rules and norms within which its economic and technical advantages will be used. After the analysis of existing approaches of definition of regional competitiveness, we came to the conclusion that the creation of the effective macroeconomic and institutional environment will facilitate to the completion of the market economy transformation and effective integration into the world economic space, reduction of transaction costs of economic entities of the region and, as a result, increase of the efficiency of resource use.

In our opinion, all determinant factors of sustainable competitiveness of the region should be combined into two groups: institutional benefits (the quality of public institutions, the quality of state institutions) and macroeconomic advantages (macro-economic factors, status, and use of technology) (Fig. 1).

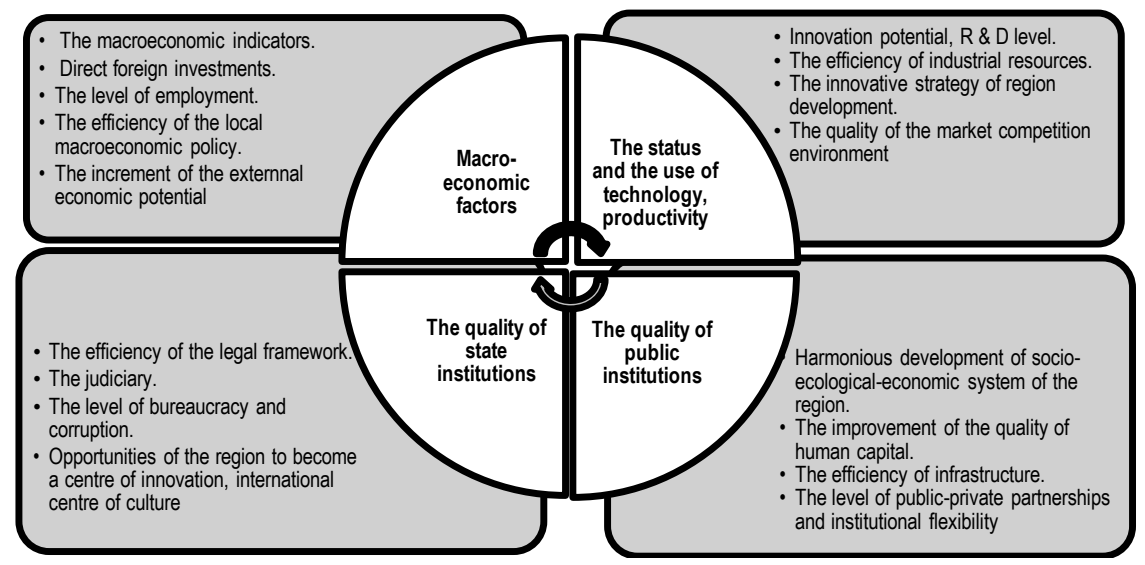

Figure 1 - Macroeconomic and institutional effective factors of the region competitiveness in the conditions of globalization of the world economic relations (authors' compilation)

A healthy macroeconomic environment is important in creating the right competitive advantages of the region of the country. Due to the fact that the state regulation of functioning of regions of Ukraine is carried out by a number of government authorities within their powers determined by the current legislation, the development of a particular region of Ukraine depends on a number of conditions created by these bodies and their interaction. As you know, currently many draft laws on the development of the decentralization process in Ukraine are regarded.

It is considered that The European Charter of Local Self-Government is a reference point for Ukraine, as well as for other European countries. It is a model of the formation of modern democratic 
and effective governance that is based on the principles of local autonomy. Ukraine has signed the European Charter in full without reservations and agreed to adopt the principles and standards of this document and adhere to them. The Ukrainian government signed the Charter and the Parliament ratified it in July 1997 [13, p. 14]. The mechanism of impact of macroeconomic factors, in practice, is strengthened by the efficiency of the institutional environment.

Therefore, Ukrainian scientists specify that in the conditions of globalization the implementation of effective foreign policy the factors associated not with the geographical location of the state and its territorial spatial characteristics, but the complex of socio-economic and technological factors that are inherent in the information of society are more important [14, p. 261]. In recent decades, the attention of the representatives of different scientific schools to the institutional aspects in the analysis of economic growth has increased significantly; it is also connected with the study of the processes of market transformation. The matter is that the use of traditional macroeconomic tools to conduct reforms has led to different results, and often to the results which were not expected by the reformers. The reaction of macroeconomic variables to measures of economic policy depends on the institutional environment. However, the degree of dependence of these results from the institutional features of a particular country has depreciated. The experience of the countries with transitive economy, including Ukraine, shows that the main among the internal factors of the market investment environment are the institutional factors associated with the development of market social norms and stereotypes of economic behaviour, and both formal and informal.

In modern conditions of extension of globalization processes, the role and importance of the active regional policy increases, where the problem of effective use of economic potential of the region due to its macroeconomic and institutional competitive advantages has become extremely actual. Modern regional development of Ukraine shows the extension of negative tendencies, especially, the deepening of regional disproportions, exacerbation of the economic and social problems of the regions due to the lack of an effective system of implementation of the state regional policy and the formed organizational and economic mechanism of increase of region competitiveness and so on.

Under the influence of the processes of economic globalization, the existing competitive advantages of the region can be levelled (Fig. 2).

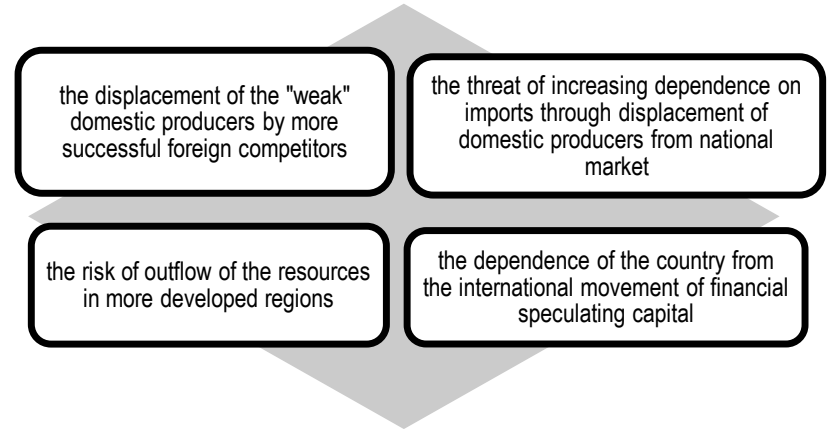

Figure 2 - "The Diamond" of potential hazards from the process of globalization of economy of Ukraine (authors' compilation)

To increase the efficiency of realization of competitive advantages of the region, we suggested the mechanism of increase of region competitiveness, taking into consideration the macroeconomic and institutional formation of effective factors and dangerous factors of the current globalization in the socioeconomic sphere (Fig. 3). 
О.В. Баула, Н.М. Галазюк, О.М. Зелінська. Концептуальні засади формування організаційно-економічного механізму підвищення конкурентоспроможності регіону в умовах глобалізації світогосподарських зв'язків

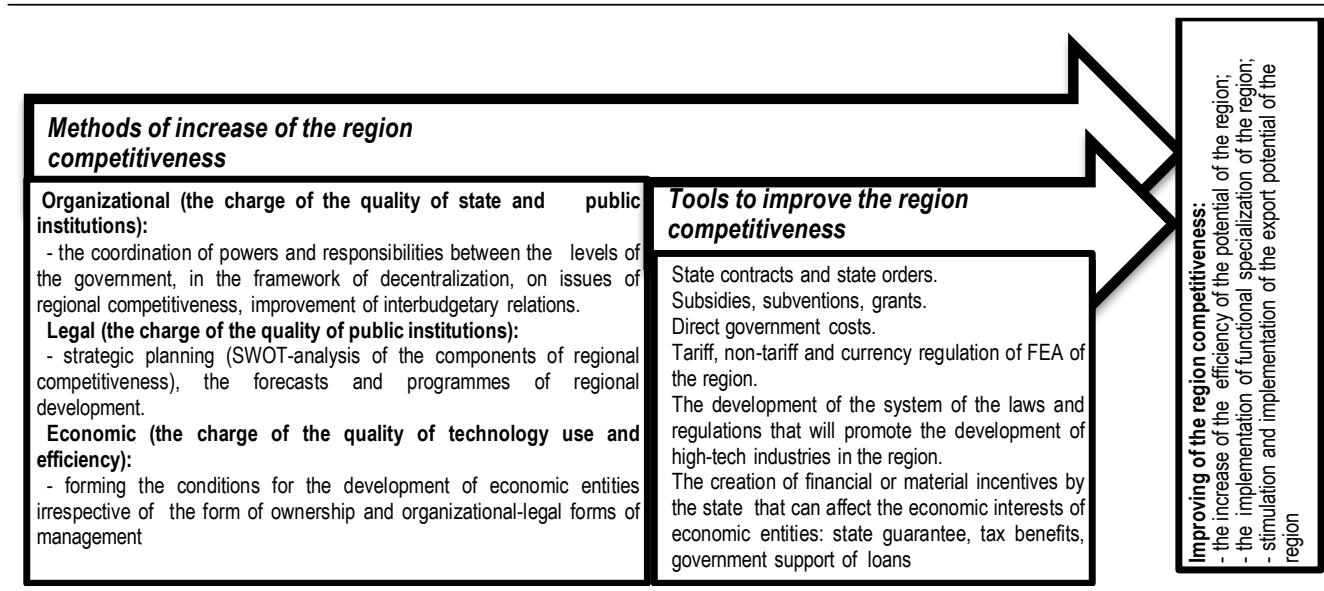

Figure 3- Organizational-economic mechanism of increase of region competitiveness in the conditions of globalization of world development (authors' compilation)

The state regional policy should be directed to effective use of competitive advantages of the region with the aim of achieving the strategic goals of sustainable socio-economic development of the country. The globalization process requires the use of the mechanism of ensuring of region competitiveness a differentiated approach in determining the methods of regional policy and the specific tools. The regulation of regional development should be aimed at strengthening macroeconomic and institutional competitive advantages the formation of effective factors) due to the high quality opportunities for power decentralization through the reduction of direct financial assistance and use of preferences and guarantees.

Conclusions. Summing up, we note that Ukraine is characterized by uneven distribution of raw materials base that is why the development of regions of the country is not uniform. However, each region of the country is characterized by its unique set of competitive advantages: macroeconomic and institutional formation of effective factors, the use of which requires a differentiated approach when choosing methods and instruments of regional policy, especially in terms of power of decentralization. Therefore it stands in need of a new vision of regional policy on the basis of formation of socio economic development models of the regions, and our future research will focus on it.

The formation of socio-economic development models of the regions will make it possible to develop a system of regulation of the region competitiveness of Ukraine from the perspective of national interests, namely the use of innovative potential of the region, ensure the diversity of the regions, interregional cooperation system.

Further studies will be directed at the search of the most efficient ways of ensuring the competitiveness of the regions of Ukraine in the context of the revealed institutional and macroeconomic benefits. In particular, effective factors of the region competitiveness which are highlighted in the article give the opportunity to pick up such a tool of regional economic policy of the government, the integrated use of which will ensure sustainable development of the national economy.

1. Андерсон В.М. Регіональна конкуренція як фактор соціально-економічного розвитку України в умовах глобалізації/ В.М. Андерсон [Електронний ресурс]. - Режим доступу: http://www.kennan.kiev.ua/kkp/content/conf06/ papers/Anderson.html.

2. Антонюк Л.Л. Виробнича конкуренто-спроможність регіонів України / Л.Л. Антонюк, В.І. Сацик // Актуальні проблеми економіки. - 2011. - № 5 (119). - С. 149-161.

3. Безугла В.О. Основи формування конкуренто-спроможності регіонів України (на прикладі Полтавського регіону) автореф. дис. ... канд. екон. наук : 08.10.01 «Розміщення продуктивних сил і регіональна економіка» / В.О. Безугла ; Харк. нац. акад. міськ. г-ва. - Х., 2006. - 20 с. 
4. Брюна Э. Сравнительний анализ конкурентоспособности российских и французских регионов [Электронный ресурс] / Э. Брюна, А.Ю. Скопин. - Режим доступа: http://www.hse.ru/ data/632/480/ 1238/Brana.pdf.

5. Герасимчук 3.В. Конкурентоспроможність регіону: теорія, методологія, практика : монографія / 3.В. Герасимчук, Л.Л. Ковальська. - Луцьк : Надстир'я, 2008. - 248 с.

6. Калюжнова Н.Я. Конкурентоспособность регионов: теория и методология анализа в контексте современного экономического развития : автореф. дис. ... д-ра экон. наук : 08.00.01, 08.00.05 / Н.Я. Калюжнова ; МОИ РФ. Иркутск, гос. ун-т. - Иркутск, 2004. - 40 с.

7. Лютак О.М. Проблеми інформаційного забезпечення розрахунку макроекономічних показників у транскордонному регіоні / О.М. Лютак // Актуальні проблеми економіки. - 2011. - № 10(124). - С. 276-284.

8. Портер Майкл Э. Конкуренция / Портер Майкл Э. ; Пер. с англ. - М. : Издательский дом “Вильямс", 2005. - 608 с.

9. Портер М. Международная конкуренция: конкурентные преимущества стран / Майкл Э. Портер ; пер. с англ. - М. : Междунар. отношения, 1993. - 896 с.

10. Селезнев А.З. Конкурентные позиции и инфраструктура рынка России / А.З. Селезнев. - М. : Юристь, 1999. - 383 с

11. Сміт А. Добробут нації. Дослідження про природу та причини добробуту нації / А. Сміт ; пер. 3 англ. під ред. Є. Литвина. - K. : Port-Royal, 2001. - 590 c.

12. Фактори і механізми забезпечення конкуренто-спроможності регіону : наук. доп. / наук. ред. П.Ю. Бєлєнький. Львів : ІРД НАН України, 2005. - 145 с.

13. Федулова С.О. Економіка старопромислових регіонів України: сучасне розуміння та реалії [Електронний ресурс] С.О. Федулова // Економіка: реалії часу. - 2015. - №4(20). - С.12-19. - Режим доступу: http://economics.opu.ua/files/archive/2015/No4/12-19.pdf.

14. Шергін С.О. Трансформація геополітичної ідентичності України в контексті українсько - російських відносин / С.О. Шергін // Наукові праці історичного факультету Запорізького національного університету. - 2010. - Вип. XXIX. - С. $258-265$.

15. Asheim B. Regional Innovation System: The integration of Local "Sticky" and global "Ubiquitous" Knowledge / B. Asheim, A. Isaksen // Jornal of Technology Transfer. - 2002. - Vol.27, Issue 1. - PP. 77-86.

16. Begg I. Cities and competitiveness / I. Begg // Urban Studies. - 1999. - Vol. 36. - P. 795-809.

17. Enright M.J. Regional Clusters: What we know and what we should know / M.J. Enright // Paper prepared for the Kiel Institute International Workshop on Innovation Clusters and Interregional Competition, 2002. - $25 \mathrm{p}$.

18. Gardiner B. Competitiveness, productivity and economic growth across the European regions / B. Gardiner, R. Martin, P. Tyler. - London : RegionalStudies.SpeciallssueDec. 2004, 38(9). - P. 1045-1067.

19. Jensen-Butler C. Competition between cities, urban performance and the role of urban policy: a theoretical framework // European cities in competition / Edited bu C. Jensen-Butler, A.Shachar and J. van Weeser. - Avebury : European science foundation, 1997. - P. 3-42.

20. Lundvall B. The Learning Economy / B. Lundvall, B. Johnson // Journal of Industry Studies. - 1994 - Vol 1. - P. $23-42$.

1. Anderson, V.M. (2006). Rehionalna konkurentsiia yak faktor sotsialno-ekonomichnoho rozvytku Ukrayiny $v$ umovakh hlobalizatsiii [Regional competition as a factor of social and economic development of Ukraine in the context of globalization]. Ahora. Podolannia rozbizhnostei - rozvytok osoblyvostei - Agora. Overcoming differences - development features, 4, 66-72. Retrieved from http://www.kennan.kiev.ua/kkp/content/conf06/ papers/Anderson.html [in Ukrainian].

2. Antoniuk, L.L., \& Satsyk, V.I. (2011). Vyrobnycha konkurentospromozhnist rehioniv Ukrainy [Industrial competitiveness of the regions of Ukraine]. Aktualni problemy ekonomiky - Recent economic problems, 3, 229-241 [in Ukrainian].

3. Bezuhla, V.O. (2006). Osnovy formuvannia konkurentospromozhnosti rehioniv Ukrainy (na prykladi Poltavskoho rehionu) [Fundamentals formation of regional competitiveness of Ukraine (on the example of Poltava region)]. Extended abstract of candidate's thesis. Kharkiv: Kharkivska natsionalna akademia miskoho hospodarstva [in Ukrainian]

4. Bryuna, E., \& Skopyn, A. (n.d.). Sravnitelnyi analiz konkurentosposobnosti rossiiskikh i frantsuzskikh rehionov [Comparative analysis of the competitiveness of the Russian and French regions]. Retrieved from https://www.hse.ru/data/632/480/1238/Bruna.pdf [in Russian].

5. Herasymchuk, Z.V., \& Kovalska, L.L. (2008). Konkurentospromozhnist rehionu: teoriia, metodolohiia, praktyka [The competitiveness of the region: the theory, methodology, practice]. Lutsk: Nadstyria [in Ukrainian].

6. Kaliuzhnova, N.Ya. (2004). Konkurentosposobnost rehionov: teoriia i metodolohiia analiza v kontekste sovremennoho ekonomicheskoho razvitiia [The competitiveness of the regions: the theory and methodology of the analysis in the context of modern economic development]. Extended abstract of Doctor's thesis. Irkutsk: Irkutskii hosudarstvennyi universitet [in Russian].

7. Liutak, O.M. (2011). Problemy informatsiinoho zabezpechennia rozrakhunku makroekonomichnykh pokaznykiv u transkordonnomu rehioni [The problems of information support of macroeconomic indicators in the calculation of the cross-border region]. Aktualni problemy ekonomiky - Recent economic problems, 10(124), 276-284 [in Ukrainian].

8. Porter, Maykl E. (2005). Konkurentsiia [Competition]. Moscow: Izdatelskii dom "Viliams" [in Russian].

9. Porter, Maykl E. (1993). Mezhdunarodnaia konkurentsiia: konkurentnye preimushchestva stran [International competition: competitive advantage of the countries]. Moscow: Mezhdunarodnye otnosheniia [in Russian].

10. Selezniov, A.Z. (1999). Konkurentnye pozitsii i infrastruktura rynka Rossii [Competitive position and the Russian market infrastructure]. Moscow: Yurist [in Russian].

11. Smit, A. (2001). Dobrobut natsii. Doslidzhennia pro pryrodu ta prychyny dobrobutu natsii [Wealth of Nations. The study of the nature and cause of the welfare of the nation]. (Ye. Lytvyna, Trans). Kyiv: Port-Royal [in Ukrainian].

12. Faktory i mekhanizmy zabezpechennia konkurentospromozhnosti rehionu [Factors and mechanisms of ensure the 
О.В. Баула, Н.М. Галазюк, О.М. Зелінська. Концептуальні засади формування організаційно-економічного механізму підвищення конкурентоспроможності регіону в умовах глобалізації світогосподарських зв'язків

competitiveness of the region]. (2005). P.Yu. Bielienkii (Ed.). Lviv: IRD NAN Ukrainy [in Ukrainian].

13. Fedulova, S.O. (2015). Ekonomika staropromyslovykh rehioniv Ukrainy: suchasne rozuminnia ta realii [Old industrial regions's economy of Ukraine: current understanding and realities]. Ekonomika: realii chasu - Economy: Realities time, 4(20), 12-19. Retrieved from http://economics.opu.ua/files/archive/2015/ No4/12-19.pdf [in Ukrainian]

14. Sherhin, S.O. (2010). Transformatsiia heopolitychnoi identychnosti Ukrainy v konteksti ukrainsko - rosiskikh vidnosyn [The transformation of the geopolitical identity of Ukraine in the context of Ukrainian - Russian relations]. Naukovi prats istorychnoho fakultetu Zaporizkoho natsionalnoho universytetu - Research works of History Faculty of Zaporizhzhya National University, Issue XXIX, 258-265 [in Ukrainian].

15. Asheim, B., \& Isaksen, A. (2002). Regional Innovation System: The integration of Local "Sticky" and global "Ubiquitous" Knowledge. Jornal of Technology Transfer, 27, Issue 1,77-86.

16. Begg I. (1999). Cities and competitiveness. Urban Studies, 36, 795-809

17. Enright, M.J. (2002). Regional Clusters: What we know and what we should know. Paper prepared for the Kiel Institute International Workshop on Innovation Clusters and Interregional Competition, 25.

18. Gardiner, B., Martin, R., \& Tyler, P. (2004). Competitiveness, productivity and economic growth across the European regions. London. Regional Studies. Special Issue Dec., 38(9), 1045-1067.

19. Jensen-Butler, C., Shachar, A., \& Weeser, J. (1997). Competition between cities, urban performance and the role of urban policy: a theoretical framework. Europan cities in competition. Avebury. European science foundation, 3-42.

20. Lundvall, B., \& Johnson, B. (1994). The Learning Economy. Journal of Industry Studies, 1, 23-42.

О.В. Баула, канд. екон. наук, доцент, доцент кафедри економічної теорії та міжнародної економіки, Луцький національний технічний університет (м. Луцьк, Україна);

Н.М. Галазюк, канд. екон. наук, доцент, доцент кафедри економічної теорії та міжнародної економіки, Луцький національний технічний університет (м. Луцьк, Україна);

О.М. Зелінська, канд. екон. наук, доцент, доцент кафедри економічної теорії та міжнародної економіки, Луцький національний технічний університет (м. Луцьк, Україна)

Концептуальні засади формування організаційно-економічного
зонкурентоспроможності регіону в умовах глобалізації світогосподарських зв'язків

механізму підвищення

Виокремити макроекономічні та інституиійні чинники формування конкурентних переваг регіону, зважаючи на які розробити концептуальні засади організаційно-економічного механізму підвищення конкурентоспроможності регіону в умовах глобалізаційного розвитку світового господарства. На основі проведеного теоретичного аналізу конкурентних переваг регіону, узагальнення та систематизації поглядів вчених-економістів, виокремлено макроекономічні та інституційні ефектоутворюючі чинники конкурентоспроможності регіону, запропоновано організаційно-економічний механізм підвищення конкурентоспроможності регіону в умовах глобалізації світогосподарських зв'язків. Удосконалено концептуальні засади формування організацийно-економічного механізму підвищення конкурентоспроможності регіону в умовах глобалізаиі світогосподарських зв'язків, які, на відміну від існуючих, передбачають врахування макроекономічних та інституційних конкурентних переваг, що гарантуватиме цілісність держави через забезпечення сталого розвитку усіх регіонів країни.

Ключові слова: конкурентні переваги, конкурентоспроможність регіону, сталий розвиток регіону, механізм управління конкурентоспроможністю регіону, глобалізація світогосподарських зв'язків.

E.B. Баула, канд. экон. наук, доцент, доцент кафедры экономической теории и международной экономики, Луцкий национальный технический университет (г. Луцк, Украина):

Н.Н. Галазюк, канд. экон. наук, доцент, доцент кафедры экономической теории и международной экономики, Луцкий национальный технический университет (г. Луцк, Украина);

О.Н. Зелинская, канд. экон. наук, доцент, доцент кафедры экономической теории и международной экономики, Луцкий национальный технический университет (г. Луцк, Украина)

Концептуальные основы формирования организационно-экономического механизма повышения конкурентоспособности региона в условиях глобализации мирохозяйственных связей

Выделить макроэкономические и институционные факторы формирования конкурентных преимуществ региона, принимая во внимание которые, разработать концептуальные принципы организационно-экономического механизма повышения конкурентоспособности региона в условиях развития глобализации мирового хозяйства. На основе проведенного теоретического анализа конкурентных преимуществ региона, обобщения и систематизации взглядов ученых-экономистов, выделены макроэкономические и институционные факторы конкурентоспособности региона. Предложен организационно-экономический механизм повышения конкурентоспособности региона в условиях глобализации мировых связей. Усовершенствованы концептуальные принципы формирования организационноэкономического механизма повышения конкурентоспособности региона в условиях глобализации мировых связей, которые, в отличие от существующих, предусматривают учитывание макроэкономических и институционных конкурентных преимуществ, которое будет гарантировать иелостность государства через обеспечение устойчивого развития всех регионов страны.

Ключевые слова: конкурентные преимущества, конкурентоспособность региона, устойчивое развитие региона, механизм управления конкурентоспособностью региона, глобализация мировых связей.

Отримано 06.12.2016 p. 